\title{
GENDER REPRESENTATION ON THE TRIBUNALS OF THE UNITED NATIONS INTERNAL JUSTICE SYSTEM: A RESPONSE TO NIENKE GROSSMAN
}

\author{
Memooda Ebrahim-Carstens*
}

Shylock: Most learned judge, a sentence! Come prepare!

Portia: This bond doth give thee here no jot of blood; The words expressly are "a pound of flesh."

(The Merchant of Venice, Act 4, Scene1)

In her interesting study on "Achieving Sex Representative International Court Benches," Nienke Grossman observes that international judgeships are often based on personal networks and social currency, or used to reward political loyalty or to advance political agendas, rather than to select the most qualified candidates. She illustrates how nomination procedures for international benches generally lack transparency, and horse-trading infects elections to the international courts. To ensure gender equity, Grossman advocates that states should take remedial steps to make nomination and selection procedures more open, transparent, and merit-based, at both the national and the international level.

The UN system of administration of justice offers a success story of how gender representation can be achieved in international tribunals. Starting operations in 2009, and comprised of a first instance United Nations Dispute Tribunal (UNDT) and an appellate United Nations Appeals Tribunal (UNAT), this judicial system has made remarkable strides in the representation of women on the bench, and right from the beginning set a trend that contrasts with the declining number of women on other international court benches. ${ }^{2}$ Furthermore, the UN experience illustrates how gender equity can be achieved without imposing gender quotas, thanks to the discrete and distinctive character and nature of its selection and recruitment processes. Therefore, the UN system may serve as a model for other jurisdictions, but also raises a question as to why women judges could achieve such status in this specific area of international administrative law.

\section{The Internal Justice System of the United Nations}

The UNDT and the UNAT constitute the formal part of the new UN internal justice system that replaced the former United Nations Administrative Tribunal (UNAdT); they are judicial bodies mandated to adjudicate employment disputes brought by the staff members of the United Nations against the Organization. By Resolution 63/253, the General Assembly adopted the statutes establishing the

* Judge, United Nations Dispute Tribunal.

Originally published online 09 September 2016.

1 See Nienke Grossman, Achieving Sex-Representative International Court Benches, 110 AJIL 82 (2016).

${ }^{2}$ In mid-2015 women made up 20\% or less on nine of twelve international courts surveyed of varied size, subject matter jurisdiction, and global and regional membership: See $\underline{i d}$. 
new, independent, transparent, professionalized, adequately resourced and decentralized system of administration of justice consistent with the relevant rules of international law and the principles of the rule of law and due process to ensure respect for the rights and obligations of staff members and the accountability of managers and staff members alike.

Judges of both tribunals are appointed for a seven-year term. However, when the first judges were appointed, the terms of office were determined by the drawing of lots, to determine three-year terms for one full-time and one half-time judge of the dispute tribunal, and three judges of the appeals tribunal. This procedure was adopted in order to stagger the appointments, to avoid the problems attendant upon a new full set of judges being appointed for each tribunal every seven years. ${ }^{3}$

Presently, in the UNDT, all three full-time judges are female; two of three ad litem judges are female, whilst the two half-time judges are male. As of 1 July 2016, four of the seven UNAT judges are female. The past and current composition of both Tribunals illustrates an interesting pattern in gender distribution on both benches:

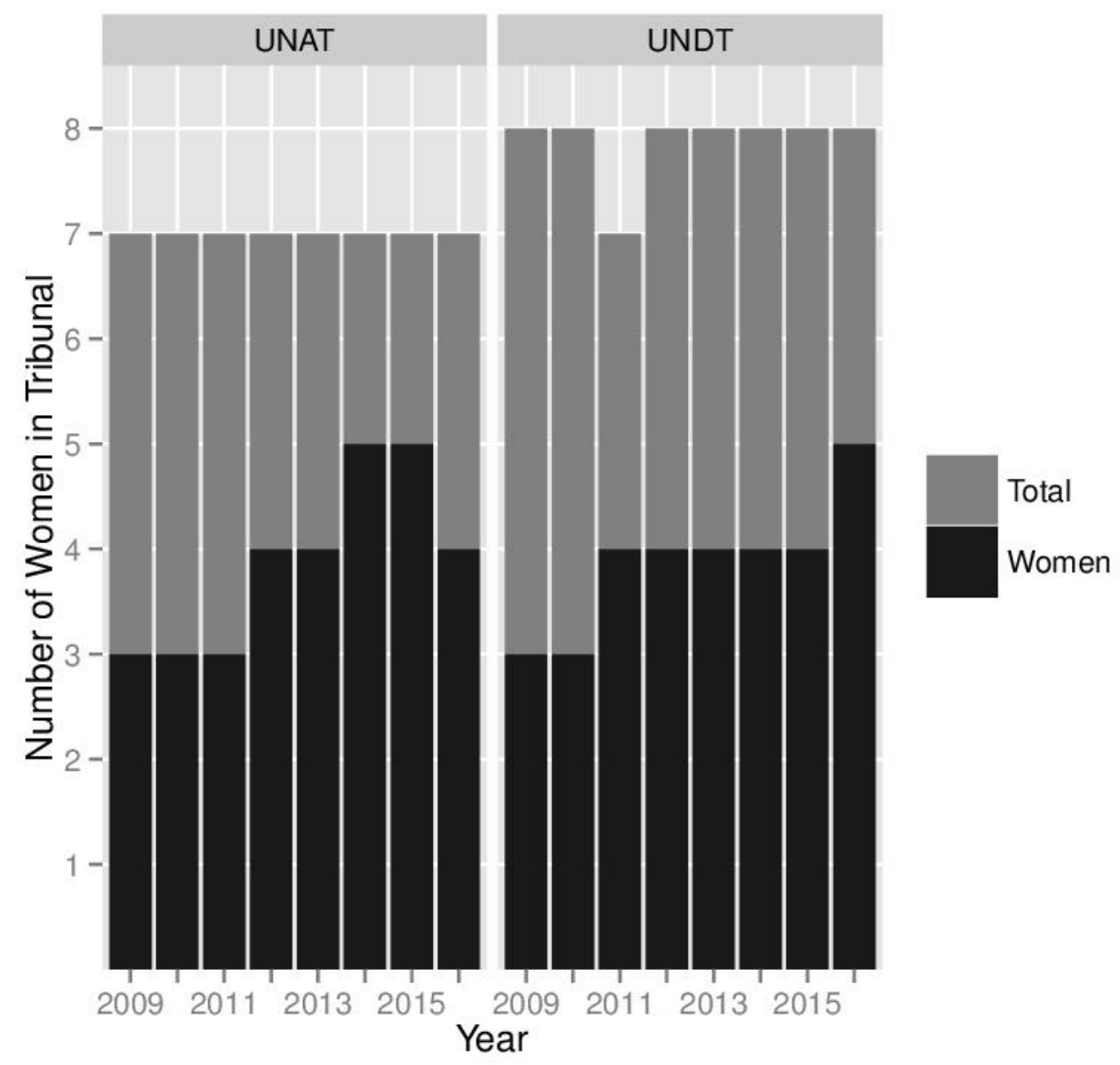

The above graph illustrates that there has always been adequate gender representation at the UNDT and UNAT, and that there is actually an increase in the number of women judges in the tribunals. This percentage

\footnotetext{
${ }^{3}$ Vacancies have therefore arisen when the three-year terms had expired, when casual vacancies arose, and when the first judicial transitions as per the statutes took place.
} 
of female representation on the UN benches is neither accidental nor serendipitous, and is due to several distinctive features and attributes of the new system.

\section{Statutory Requirements}

The UNDT statute provides for three full-time judges, (based in Geneva, Nairobi, and New York respectively), and two part-time judges. ${ }^{4}$ Three ad litem judges were initially appointed for each duty station as a transitional measure, for a term of one year to clear the backlog of old cases inherited from the former UNAdT; these judicial posts have been extended on an annual basis by the General Assembly for the last seven years. Unlike the former system, and in keeping with the principles of access to open justice and transparency, extensive use of oral hearings is made in the UNDT. Cases are normally considered by a single judge, although a panel of three may be constituted by reason of the particular complexity or importance of a case. The UNAT is composed of seven judges; it holds three sessions a year and sits in panels of three.

Consistent with the UN Charter, ${ }^{5}$ the statutes of both tribunals provide that the judges shall be appointed by the General Assembly on the recommendation of the Internal Justice Council (IJC) and stipulates that "no two judges shall be of the same nationality" and further that "due regard shall be given to geographical distribution and gender balance." 6

This mandatory language as will be seen below, impacts positively on the selection, nomination, and election of the judges to both tribunals.

\section{The Internal Justice Council: An Independent Nominating Body}

The IJC is an independent, gender- and geographically-diverse representative body, chaired by an eminent international jurist (Kate O'Regan of South Africa being the first Chair, followed by current Chair Justice Ian Binnie of Canada). It is composed of a management representative, a staff representative, and two external distinguished jurists nominated by management, and the Staff Association respectively. The IJC, at the conclusion of a rigorous selection exercise, presents a full written report to the General Assembly to which is annexed a copy of the vacancy announcement and the detailed curriculum vitae of two recommended candidates for each post. 7 In this report, the IJC explains the method and process for selection, and makes recommendations to the General Assembly for the appointment of the candidate judges, providing guidance on the statutory requirements. ${ }^{8}$

In compliance with the language of the statutes, and in order to give effect to the spirit of the UN Charter, the IJC has devised a robust, unique system of recruitment and selection.

${ }^{4}$ UNDT Statute art. 4(1) (adopted by GA Res. 63/253 (Dec. 24, 2008) and amended by GA Res. 69/203 (Dec. 18, 2014) and GA Resolution 70/112 (Dec. 14, 2015)).

5 The Preamble to the UN Charter reaffirms the faith in "fundamental human rights, in the dignity and worth of the human person, in the equal rights of men and women." and Article 1.3 of the Charter "promotes respect for human rights and for fundamental freedoms for all without distinction as race, sex, language, or religion."

${ }^{6}$ UNDT Statute art. 4(2) (adopted by GA Res. 63/253 (Dec. 24, 2008) and amended by GA Res. 69/203 (Dec. 18, 2014) and Resolution A/70/112 (Dec. 14, 2015)) and UNAT Statute art. 3(2) (adopted by GA Res. 63/253 (Dec. 24, 2008) and amended by GA Res. 66/237 (Dec. 24, 2011), GA Res. 69/203 (Dec. 18, 2014), and GA Res. 70/112 (Dec. 14, 2015)).

7 See, e.g., Report of the Internal Just. Council, UN Doc. A/70/190 (Aug. 14, 2015) and Report of the Internal Just. Council, UN Doc. A/69/373 (Sep. 19, 2014)—(although two to three candidates may be recommended—GA Res. 62/228 para. 37 (B)).

8 See, e.g., Report of the Internal Just. Council, UN Doc. A/70/190 (Aug. 14, 2015). 


\section{Recruitment}

The character and quality of recruitment and selection procedures is of utmost importance as there is no doubt that lack of transparency and the closed nature of the normal nomination processes impact negatively on female representation.

Perhaps the most unique feature of the UN internal justice system is the method of selecting the pool of candidate judges by way of advertisement in the international public press and more, inviting applicants globally to apply on an individual basis rather than by way of state nomination. The vacancy announcement of March 2015 for the UNDT selections for example, was posted on the website of the Office of Administration of Justice in both English and French and included the following sentence in bold "applications from women are strongly encouraged." A short version of the advertisement with a link to the full announcement was published in both online and printed editions of several leading journals: Le Monde, the Wall Street Journal Asia edition, the Economist, the International New York. Times, and Jeune Afrique. The vacancy announcement was also attached to a note verbale addressed to all the permanent missions in the United Nations in New York, Geneva, and Vienna, inviting states to bring the vacancy announcement to the attention of their qualified nationals, as well as to the Chief Justice or head of the judiciary in their country. The vacancy announcement was also widely circulated to the United Nations information centres, resident coordinators, other international courts and tribunals, human resources entities in international organizations, outreach focal points in ministries and government institutions, professional associations, UN managers and networks of professional women, nongovernmental organizations, national and international bar associations, and law societies. ${ }^{9}$

It is evident from the applications received that this procedure ensures a larger pool of global competitors who can apply independently and freely, ruling out state politics, bias, and favouritism, and also assures a more representative candidature. ${ }^{10}$

\section{Merits-Based Screening and Selection}

Grossman argues that the limited pool argument is unpersuasive for a number of reasons. For one, merit plays an inconsequential role in the normal judicial selection procedures, and moreover, states with a higher percentage of female lawyers do not necessarily produce more international judges. Indeed, Botswana, a country with a population of just over two million, despite having a limited pool of professionals and scarce skills, has successfully fielded two female judges to international courts, Hon Sanji Monageng of the International Criminal Court and this writer. Justice Monageng was recommended by process of state nomination (endorsed by the African Union); whilst the writer received state support during the elections following a merit-based selection and nomination by the IJC. The African Court of Human and People's Rights recently appointed two women judges, and the African Union (AU) has resolved that for the eleven-judge bench "the remaining two judges shall be elected in January 2017 only from among female candidates from the Northern and Southern regions, in respect of equitable geographical and gender representation in AU organs."11 Whilst the presence

${ }^{9} \underline{I d}$. at para. 14 .

${ }^{10} \underline{I d}$. at para. 16:

the Council received 182 applications from 51 different countries. A total of 45 applicants were from Africa, 12 from Asia and the Pacific, 15 from Eastern Europe, 24 from Latin America and the Caribbean, and 84 from Western Europe and other states. Of the applicants, 117 were male and 65 were female.

11 27th AU Summit 10-18 July 2016 Kigali Rwanda: 2016: African Year of Human Rights with particular focus on the Rights of $\underline{\text { Women. }}$ 
of state and/or regional political will cannot be gainsaid, a healthy gender sensitive culture at all levels is imperative, as has been the experience of this writer who received outstanding support from the Botswana bar, bench, and state.

In the UN experience the global pool method utilized by the IJC inviting individual applications, coupled with a merits-based selection exercise has not precluded the substantial number of female candidates. Indeed, it has resulted in a majority female presence on both benches.

Another distinguishing feature of the UN system is that the preliminary selection and screening is very much merits-based. To be eligible for appointment to the UNDT, an applicant must be of high moral character and have at least ten years of judicial experience or the equivalent, with fifteen years' experience required for the UNAT. $^{12}$ Applicants are required to submit a curriculum vitae together with a writing sample (judgment or opinion), with their application, as well as the names and addresses of two senior legal professionals, able to attest to the moral character and professional standing of the candidate. Thereafter, eligible candidates are invited by the IJC to undergo a three hour written examination to test their legal expertise, judicial analysis, and drafting ability. The IJC then selects applicants to be interviewed by the Council based on the written assessments, which are graded "blindly" by the Council members, ${ }^{13}$ following which the candidates are shortlisted if their respective bar council clears them. The IJC thereafter in a detailed report recommends two candidates per post for election to the General Assembly. ${ }^{14}$ It is only at the General Assembly voting stage that there may be state involvement, lobbying, or horse-trading in the two-horse race.

\section{Elections}

The election of judges by the General Assembly is done by secret ballot. The procedure followed in the General Assembly for the appointment of judges is in accordance with the statute of the tribunals, the rules of procedure of the General Assembly, and upon the recommendations of the Internal Justice Council as set out in its report to the General Assembly. The fundamental distinction with the UN system is that state support, if required during the election process, and horse-trading if any, follows a merit-based nomination, sourced from a global pool, by an independent body, the IJC. Furthermore, the General Assembly itself in the election process entreats Member States to consider gender when casting their votes.

In his Memorandum A/70/538 dated 4 November 2015, the Secretary-General proposed that:

the General Assembly proceed to appoint the judges through an election, held pursuant to the rules of procedure of the Assembly, bearing in mind paragraph 58 of Assembly resolution 63/253, in which the Assembly invited Member States, when electing judges to the Tribunals, to take due consideration of geographical distribution and gender balance. ${ }^{15}$

12 UNDT Statute art. 4(3) (adopted by GA Res. 63/253 (Dec. 24, 2008) and amended by GA Res. 69/203 (Dec. 18, 2014) and Resolution A/70/112 (Dec. 14, 2015)) and UNAT Statute art. 3(3) (adopted by GA Res. 63/253 (Dec. 24, 2008) and amended by GA Res. 66/237 (Dec. 24, 2011), GA Res. 69/203 (Dec. 18, 2014), and GA Res. 70/112 (Dec. 14, 2015)).

13 See Report of the Internal Just. Council, UN Doc. A/70/190, para. 21 (Aug. 14, 2015): the Office of Administration of Justice sends the completed examinations to each member "having eliminated all identifying elements from them so that no Council member would know the name, nationality or gender of the candidate."

${ }^{14}$ The Council selects the best candidates "on the basis of experience, drafting ability, and legal analysis, geographic distribution and gender for presentation to the General Assembly." See Report of the Internal Just. Council, UN Doc. A/69/373, para. 21 (Sep. 19, 2014).

15 See Memorandum of the Secretary-General, UN Doc. A/70/538, para. 21 (Nov. 4, 2015). 
Pursuant thereto, during the elections on 18 November 2015, the President of the General Assembly invited the Member States "when electing judges to the United Nations Dispute Tribunal and the United Nations Appeals Tribunal, to take due consideration of geographical distribution and gender balance."16

Indeed, at least two female judges in the last seven years have experienced that even in the absence of overt state support, they were successfully elected, no doubt as the Member States took gender balance into account.

The General Assembly in electing judges to both the UNDT and UNAT benches therefore takes into consideration the explicit wording of the statute, and the recommendations of the IJC, which independently vets and screens the recommended candidates prior to election.

\section{Perceptions of Gender-Based Specialization}

The General Assembly required that the new system of justice be "consistent with the relevant rules of international law and the principles of the rule of law and due process to ensure respect for the rights and obligations of staff members and the accountability of managers and staff members alike."

One possible remaining concern is that judges' prior experiences, and in particular their areas of specialization could be marshaled inappropriately to exclude women. The UN experience with judges with diverse prior experiences speaks to these concerns.

Of the seven women who have served or are currently serving on the UNDT, four have specialized employment/labor court experience, one has labor and administrative law experience from courts of general jurisdiction (in three countries), and two have international court experience (UNMIK and UNIKART-the Kosovo and Cambodia tribunals).

Of the seven men who have served or are currently serving on the UNDT, two have specialized employment/labor court experience (one of whom also has international court experience with UNMIK Kosovo), two have administrative law experience from specialized courts, and two from courts of general jurisdiction (one of whom also served on UNMIK and UNIKART).

The UN experience shows that familiarity with and capacity to apply the "relevant rules of international law and the principles of the rule of law and due process" is not the sole preserve of either sex, it is very much a matter of individual qualification, interest and legal tradition. In the case of the UN administrative tribunals, therefore, adequate gender representation could be achieved thanks to a merit-based selection mechanism, which avoids the other considerations extraneous to the judicial function take a role in the appointment process. The question that arises is whether this mechanism could serve as a model for other jurisdictions, or whether it was successful due to the specificity of the jurisdiction ratione materiae of these tribunals, which involve issues of labor, contract, and administrative law in which women judges are already quite present at the national level.

The identification of women with soft law or "pink law" issues is misguided. Subject matter should not be determinant of the composition of a bench. There is no mystery or secret to the application of international law and the principles of the rule of law and due process; or for that matter judicial reasoning in any field. There should be no sole preserve subject matter for either gender, lest women have to don forever the garb of man in order to play an effective role in settling disputes in the most enterprising manner, as did Portia.

\section{The UN Internal Justice System: Model for a Representative Bench?}

There is no doubt that lack of transparency and the closed nature of the normal nomination processes impact negatively on female and minority representation. The UN experience provides answers to some of the

16 See UN GAOR, 70th Sess., 57th plen. mtg. at 3, UN Doc. A/70/PV.57 (Nov. 18, 2015). 
challenges identified by Grossman. It illustrates that tasking an independent and truly representative selection body of eminent persons such as the IJC with the selection and nomination of its international judges lends legitimacy, independence, and confidence to a process which unashamedly addresses the need for geographical and gender balance. The IJC's transparent modus operandi including a global public recruitment drive inviting individual applications, a rigorous merit-based selection, and the compilation of an objective and transparent report making recommendations to the electing body, must be the way to go. The UN model clearly illustrates that maximizing transparency and removing subjective nominations in the selection process not only redresses sex balance on the bench, but also places the best candidates on the job.

Perhaps it is time for international courts to review their statutes and selection procedures in line with the selection and appointment procedures under the new system of justice in the United Nations. 